\title{
Party positions over international human rights treaties in the United States in the Post-Cold War
}

1. Esta pesquisa está vinculada ao Processo FAPESP número 2019/20181-6.

2. Doutor em Ciência Política pela UFSCar, Bolsista de Pós-Doutorado da Fundação de Amparo à Pesquisa do Estado de São Paulo (FAPESP) no Instituto de Políticas Públicas e Relações Internacionais (IPPRI) da Universidade Estadual Paulista (UNESP), São Paulo, Brasil. ORCID: http://orcid.org/00000002-6740-5489.

3. Mestre em Ciência Política pela UFSCar, Bolsista de Doutorado do Conselho Nacional de Desenvolvimento Científico e Tecnológico (CNPq) na Universidade Estadual de Campinas (UNICAMP), Campinas, Brasil. ORCID: https://orcid org/0000-0001-7810-0122
Posições partidárias sobre tratados internacionais de direitos humanos nos Estados Unidos no pós-Guerra Fria

\section{Posiciones partidistas sobre los tratados internacionales de derechos humanos en los Estados Unidos después de la Guerra Fría}

\author{
Flávio Contrera² \\ Matheus Lucas Hebling ${ }^{3}$
}

DOI: 10.5752/P.2317-773X.2021v9.n1.p24

Received on April 04, 2019

Accepted on April 27, 2020

\begin{abstract}
This article aimed to verify the occurrence of convergence and congruence in the positions that the Democratic and Republican parties express about human rights treaties in the Electoral, in the Executive, and the Legislative arenas, in the Post-Cold War (1992-2016). The use of the comparative method guided the study of six specific cases, analyzed using qualitative techniques. The results point to two trends. The first is that the possibility of convergence between the Democratic and Republican parties tends to diminish when their positions on human rights treaties are anchored by ideological perspectives, and the second is that a party's position on a treaty tends to be congruent among political arenas. Moreover, the divergence of positions between the parties clarifies the liberal internationalist character of the Democratic positions and the conservative isolationist approach of the Republican positions.
\end{abstract}

Keywords: Human Rights. Political Parties. Post-Cold War. Treaties. The United States.

\section{Resumo}

Este artigo teve como objetivo verificar a ocorrência de convergência e congruência nas posições que os partidos Democrata e Republicano sustentaram sobre tratados internacionais de direitos humanos nas arenas eleitoral, no Executivo e no Legislativo, no pós-Guerra Fria (1992-2016). O emprego do método comparativo orientou o estudo de seis casos específicos, analisados a partir de técnicas qualitativas. Os resultados apontam duas tendências. A primeira delas é a de que a possibilidade de convergência entre os partidos Democrata e Republicano 
tende a diminuir quando suas posições são ancoradas por perspectivas ideológicas. A segunda é a de que a posição de um partido sobre um tratado tende a ser congruente entre as diferentes arenas políticas. Além disso, a divergência de posições entre os partidos evidencia o caráter liberal internacionalista das posições democratas e a abordagem conservadora isolacionista das posições republicanas.

Palavras-Chave: Direitos Humanos. Partidos Políticos. Pós-Guerra Fria. Tratados. Estados Unidos.

\section{RESUMEN}

Este artículo tuvo como objetivo verificar la ocurrencia de convergencia y congruencia en las posiciones que los partidos Demócrata y Republicano mantuvieron sobre los tratados internacionales de derechos humanos en el ámbito electoral, ejecutivo y legislativo, en la posguerra fría (1992-2016). El uso del método comparativo guió el estudio de seis casos específicos, analizados mediante técnicas cualitativas. Los resultados apuntan a dos tendencias. La primera es que la posibilidad de convergencia entre los partidos demócrata y republicano tiende a disminuir cuando sus posiciones están ancladas en perspectivas ideológicas. La segunda es que la posición de una parte en un tratado tiende a ser congruente entre diferentes arenas políticas. Además, la divergencia de posiciones entre los partidos resalta el carácter internacionalista liberal de las posiciones demócratas y el enfoque conservador aislacionista de las posiciones republicanas.

Palabras-clave: Derechos humanos. Partidos politicos. Post-Guerra Fría. Tratados. Estados Unidos.

Introduction

Prospects for cooperation initiatives among countries have long been on the horizon of liberal theorists in international relations. Initially, these perspectives envisioned the possibility of cooperation through international organizations, which came to take effect only after World War II. In subsequent years, these perspectives focused on regional integration (DEUTSCH, 1957; HAAS, 1964; MITRANY, 1966). Since the 1970s, liberals have envisioned cooperation through the construction of international regimes (KEOHANE; NYE, 1977; KRASNER, 1982) and later, through global governance structures (ROSENAU, 1992). However, this long period of theoretical development took place during the Cold War, when the conflict between the superpowers affected the prospects for international cooperation.

The beginning of the $1990 \mathrm{~s}$, in contrast, is characterized as a moment of change and reorganization of the international system. The disintegration of the Soviet Union and the end of the bipolar conflict combined with the intensification of the globalization process have ushered in a new era in which cooperation initiatives among countries have become more feasible. In this context, the prospects for international cooperation have stimulated new enthusiasm for treaty-making as a way to solve some of the world's most pressing problems (ELSIG et al., 2011).

This is not to say that treaties are a particular post-Cold War phenomenon. Quite the opposite. However, in this new context, they have gained particular importance for States to jointly address challenges that 
transcend their borders, and that depend on a complex solution. In this sense, it is clear in the literature that the end of the Cold War-era opened up new opportunities for the further institutionalization and legalization of international politics (ELSIG et al., 2011; GOLDSTEIN et al., 2000).

This more favorable context for cooperation did not, however, prevent the United States (US), despite being the main actor in the international system, from failing to ratify a series of important treaties, among which the human rights treaties stand out. At the same time that the United States is recognized for its willingness to pressure other countries to adhere to best human rights practices, that provision is not found when it comes to the Americans themselves adhering to international human rights treaties. For this reason, the relationship of Americans with this issue has been described in the literature as paradoxical or even hypocritical (BRADLEY, 2008).

On the other hand, it has to be considered that although the rate of ratification of international treaties by the US is not among the highest in the world (ELSIG et al., 2011), this does not mean Americans are unwilling to build cooperative solutions to global problems. Effectively, the construction of international treaties involves a series of steps, which can be separated at the international and domestic levels. According to Putnam (1988), this political struggle takes the form of a two-level game involving bargaining between negotiators leading to a provisional agreement (level I) and separate discussions between domestic support groups on ratifying or not the agreement (level II).

It is precisely at the domestic level that the decision to ratify international treaties occurs. In contrast to the favorable context of cooperation at the international level, the domestic context in the US has been marked since the late 1980 s by the intensification of party polarization (BECKMANN, McGANN, 2008; BRUNELL et al., 2015; POOLE, ROSENTHAL, 1997; RAGUSA, 2016; THERIAULT, 2006).

Since political parties are the main actors responsible for approving international treaties in the U.S. Senate, two important questions emerge when we approach the positions they hold on these treaties. The first is the question of the convergence of positions, without which a treaty cannot be ratified - given the qualified majority required for it. In this scenario, how similar the Democratic and Republican parties' positions are when it comes to human rights? The second is the congruence of positions, essential for the party's responsiveness to be verified by the voter when a party manifests itself over a treaty in the different political arenas, i.e., Electoral, Executive and Legislative. Are parties' positions congruent among different political arenas?

Thereby, this article aimed to verify the occurrence of convergence and congruence in the positions that the Democratic and Republican parties express about human rights treaties in the Electoral, in the Executive, and the Legislative arenas, in the Post-Cold War. Although the small number of cases analyzed does not allow us to produce generalizations, the results point to two important trends that can be tested in future studies that are not restricted to human rights issues. The first is that the possibility of convergence between the Democratic and Republican par- 
ties tends to diminish when their positions are anchored by ideological perspectives. The second is that a party's position on a treaty tends to be congruent among different political arenas.

Much has been done to understand party polarization, but mainly in big-time series (LAYMAN, CARSEY, 2002; LEVENDUSKY, 2009). Being the comprehension of polarization methodologically, quantitatively (POOLE, ROSENTHAL, 1997), or qualitatively (HACKER, PIERSON, 2006), its relation with public opinion (FLYNN, HARBRIDGE, 2016), with the economy (MCCARTY, POOLE, ROSENTHAL, 1997) or even party pressures themselves (SNYDER, GROSECLOSE, 2000). However, this literature has yet to explore topical issues and their relation with party polarization, that being foreign policy or human rights. This gap is the one we try to fill with this work.

This article is organized into five sections. The introduction was presented in this first section. The second addresses the process of ratification of international treaties in the United States. In the third section, we presented the data and methods. In the fourth section, we discussed the findings, and, finally, in the fifth section, we concluded.

The treaty process in the United States

The process of ratification of treaties in the United States is characterized by a series of steps. While negotiation and signing of treaties take place internationally, treaties are sent to the Senate for advice and consent at the domestic level. If a treaty is approved, it is submitted to the President for ratification. This process is regulated by the Constitution, which says: "He [the President] shall have Power, by and with the Advice and Consent of the Senate, to make Treaties, provided two-thirds of the Senators present concur." (U.S. CONSTITUTION, art. II, §2).

Unlike what the constitutional text might suggest with the word "advice", the President and Senate do not negotiate treaties together. According to Scott (2002), experience has shown that a shared role in the negotiation stage was impractical. Thus, the negotiation of treaties is limited to the actors in the Executive Branch and may be authorized by both the President and the Secretary of State. After negotiations are concluded, the treaty is signed by the President. This signature, however, does not end the process, nor does it create obligations related to the treaty for the country. It is only a sign of the commitment of the United States to the act of ratification, which needs to obtain the consent of the Senate.

Thus, once the treaty has been signed, the President can submit it to the Senate through a message requesting its consent. The treaty, then, is read and forwarded to the Foreign Relations Committee (FRC), which allocates it to the calendar, where it remains until the FRC considers it. The Committee may either report the treaty to the floor or recommend its return to the President. Precisely, as Scott (2002) explains, only in three situations treaties returns to the President. In the other six possible scenarios, treaties remain in the Senate and return to the FRC at the end of the legislature. These scenarios, which are important for the understanding of the treaty process in the United States, are provided in Chart 1. 
Chart 1 - Possible Scenarios of Senate Actions on Treaties

\begin{tabular}{|l|l|l|l|}
\hline \multicolumn{2}{|l|}{ Senate Actions } & \multicolumn{2}{l|}{ The result of Senate Actions } \\
\hline $\begin{array}{l}\text { Vote on Advice and Consent to } \\
\text { Treaty }\end{array}$ & $\begin{array}{l}\text { Vote on Resolution } \\
\text { of Return }\end{array}$ & $\begin{array}{l}\text { Subsequent Location of } \\
\text { Treaty }\end{array}$ & $\begin{array}{l}\text { Article } 18 \\
\text { Obligation } \\
\text { Problem }\end{array}$ \\
\hline $\begin{array}{l}\text { 1. Greater than or equal to } 2 / 3 \text { in } \\
\text { favor }\end{array}$ & Not applicable & Returned to President & No \\
\hline 2. Less than $2 / 3$ in favor & Greater than $1 / 2$ in favor & Returned to President & No \\
\hline 3. No vote & Greater than $1 / 2$ in favor & Returned to President & No \\
\hline 4. Less than $2 / 3$ in favor & Less than $1 / 2$ in favor & Remains in Senate & Yes \\
\hline 5. Less than $2 / 3$ in favor & $\begin{array}{l}\text { Less than } 1 / 3 \text { in favor } \\
\text { (more than } 2 / 3 \text { in favor of retaining) }\end{array}$ & Remains in Senate & Yes \\
\hline 6. Less than $2 / 3$ in favor & No vote & Remains in Senate & Yes \\
\hline 7. No vote & Less than $1 / 2$ in favor & Remains in Senate & Yes \\
\hline 8. No vote & $\begin{array}{l}\text { Less than } 1 / 3 \text { in favor } \\
\text { (more than } 2 / 3 \text { in favor of retaining) }\end{array}$ & Remains in Senate & Yes \\
\hline 9. No vote & No vote & Remains in Senate & Yes \\
\hline
\end{tabular}

Source: SCOTT, 2002, p. 1476.

If the Committee fails to decide on the treaty, it can remain on the calendar indefinitely. In this regard, the Foreign Relations Committee has at this stage full decision-making power over the future of the treaty. The negotiations conducted in the international arena around the treaty are contrasted in the Senate with the conflicts that characterize the Legislative branch and the Domestic Politics.

\section{Party Convergence}

Bipartisan convergence on political issues relies on how much are the parties compromised with their ideologies. Therefore, if there is ideological polarization, the probability of parties converging on issues fades away. The political positions of Democrats and Republicans are ideologically based on liberalism and conservatism, respectively. But it was not always so. When the Republican Party emerged in 1854 it was fundamentally anti-slavery and liberal. In the 1860 presidential election, the Democrats split into two wings, north and south, the first being anti-slave and liberal and the second being pro-slave and conservative. However, about a hundred years after the end of the Civil War the parties were positioned on different ideological spectra. Throughout this period, the Democratic Party became consistently liberal while the Republican

4. Since Vietnam, presidents have endorsed human rights as part of the foreign policy agenda. At the same, they have consistently attempted to bolster American self-confidence and revive the perceived moral legitimacy of the U.S. foreign policy by rhetorically mobilizing American exceptionalism. Although the rhetoric of American exceptionalism is used by Democrats and Republicans, it should not be confused with party ideology. Party was pushed into conservatism. This was due to Democrat Woodrow Wilson adherence to labor guidelines in 1912 elections, previously associated with the Republican Party; the rise in the 1930s of the New Deal in Democrat Roosevelt's government and his policies of welfare-state; and the Democrats' adherence to the civil rights movement in the 1960s (ROSATI; SCOTT, 2011). At the end of the 1960s, the Vietnam War ${ }^{4}$ divided the parties also on foreign policy (LINDSAY, 1994; MEERNIK, 1993; NELSON; TILLMAN, 1984). Opposition to the war became central to the Democratic Party. Groups opposed to the war saw the moment as 
a historic opportunity to help redefine US foreign policy through a human rights policy (MAINWARING, 1986), that changed the fundamental nature of US-Third World relations while still protecting essential American interests (SCHMITZ; WALKER, 2004).

In contrast to that progressive movement, Republicans received support in the mid-1970s from Christian fundamentalists, pro-life groups, and others of special interest on the right. These groups played a major role in articulating an image of the United States, embodying Christian virtues and employing all available means to defeat communism, representing it as the evil force that destroys Christian values. Moreover, Carter was accused of being a weak president, especially after the disaster in Iran, the Sandinista victory in Nicaragua, and the spread of atrocities committed by the communist regimes of Cambodia and Vietnam. In this context, social movements organized by the new right demanded a more aggressive presence of the United States in the Third World (MAINWARING, 1986). Reagan's victory in 1980 led American foreign policy in this direction, reinforcing the Republican Party's reputation as a proponent of conservative positions.

Starting in the 1970s, institutional and contextual changes have contributed to a decrease in bipartisan consensus on foreign policy. In the institutional scope, the rule of representation of the parties within the Committees in the legislature changed. The percentage of representation of a party within the Senate began to determine the percentage of seats that a party is entitled to in each committee, including in the Committee on Foreign Relations. At the same time, this change gave agenda power to the majority party in each legislature and reinforced inter-party divisions as parties began to vote with greater discipline (ALDRICH, 2011; ROHDE, 1991);

Besides Vietnam, the end of the Cold War meant a substantial contextual change that affected the prospects for bipartisan convergence. External threats - as the Soviet Union was during the Cold War - are fundamental for bipartisan consensus on foreign policy. As Simmel (1904) and Coser (1956) showed, the existence of a threat can have positive consequences for group cohesion, morale, and development. In such circumstances, i.e., the existence of an external threat, Huntington (1997) argued that the United States promoted national security-related interests to deal with it. On the other hand, some authors have shown a threat absence opens an opportunity for the pursuit of parochial interests carried out by the activism of interest groups (HUNTINGTON, 1997; NYE, 1999; RICE, 2000). This was the scene after the Soviet Union's dissolution.

In the Post-Cold War era, foreign policy consensus was replaced by party disagreement and polarization. The absence of a vital threat allowed parties to reformulate their foreign policy positions (ORNSTEIN, 1992). The strategy of containment had become inadequate to deal with the fluid and diffuse threats that have gained centrality in the post-Cold War era, such as environmental degradation, illegal immigration, ethnic and religious conflicts, humanitarian emergencies, terrorism, and international crime.

Under these circumstances, we argue that there is a possibility for an even smaller consensus on foreign policy in the post-Cold War context and an increase in divergent positions between the major parties. International human rights treaties are an important element of American foreign policy. 
In this sense, identifying the positions of the parties on these treaties allows us to verify if there are cohesion and continuity in the defense of the American national interests or if these vary according to the party positions.

Scholars have acknowledged that the Democrats are seen as those who best deal with social welfare and civil rights issues, while the Republicans are seen as the most capable of dealing with the rule of law and national defense (POPE, WOON, 2008). This ideological division that characterizes parties includes foreign policy issues. Milner and Tingley (2015) argue that conservatives and liberals have different positions on trade policy, international economic aid, and domestic military spending. The authors also argue that conservatives are more hawkish on foreign policy than liberals are. Liberals would engage in interventionism only in situations where the human rights of the citizens of the countries involved are affected.

Thus, while Democrats are often classified as liberal, Republicans are considered conservative in their positions. We expect this tendency to be verified concerning the subjects analyzed here. This implies arguing that in human rights treaties the Democrats would defend liberal while the Republicans would defend conservative positions. This trend would imply the possibility of ratifying a treaty since it would make it difficult to build convergence between the parties. Considering the previous debates on parties' ideologies and positions over the time (HUNTINGTON, 1997; LINDSAY, 1994; MAINWARING, 1986; MEERNIK, 1993; MILNER; TINGLEY, 2015; NELSON; TILLMAN, 1984; NYE, 1999; POPE; WOON, 2008; RICE, 2000; ROSATI; SCOTT, 2011), the institutional changes and the prospects for polarization starting in the 1970 (ALDRICH, 2011; ROHDE, 1991) and increasing in the post-Cold War (ORNSTEIN, 1992), we have investigated the following hypothesis:

H1: The possibility of convergence between the Democratic and Republican parties tends to diminish when their positions on human rights treaties are anchored by ideological perspectives.

\section{Party Congruence}

Although the U.S. Senate is the arena in which parties' positions on treaties assume a more decisive character, parties also manifest themselves in previous or simultaneous moments in other arenas, such as in the Electoral arena and the Executive arena. Thus, during presidential elections, parties can position themselves on international treaties in their campaign manifestos. When they come to the United States Presidency, the party in the Executive can also express positions on treaties in the documents that organize the foreign policy guidelines of the Administration. In this regard, the National Security Strategy, edited by the National Security Council and the Strategic Plan for International Affairs, edited by the Department of State and the United States Agency for International Development (USAID), stands out.

When parties took positions in the Electoral arena and the Executive branch, more than signaling their positions on the treaties to legislators, they seek to shape the positions of the legislators themselves so that there is party congruence around the subject of the treaty. This is 
a key issue for contemporary democracies. It involves the perspective of the responsiveness of elected political representatives to the demands of citizens (DAHL, 1971). As policy-seekers, voters choose the party manifesto in the Electoral arena that most closely matches their preferences (DOWNS, 1957).

In this regard, the voter's vote is not only perspective but also retrospective. Considering that if the voter is satisfied with the government performance of the previous period, he will keep his vote in the same party. Otherwise, he will support another. Thus, motivation stemming from the fact that parties are office-seeking and that the fear of retaliation by voters would act as incentives to motivate governments to be responsive to voters (HOFFERBERT; BUDGE, 1992).

Responsiveness is measured by the positions that the parties manifest in the Electoral, Executive and Legislative arenas. In other words, if there is congruence in the positions held by the parties on human rights treaties, there would be responsiveness. Thus, if the parties are responsive, we understand that there is a greater probability of congruence between the positions defended by them in the Electoral arena and the Senate; or otherwise, among the positions advocated by the winning party in the Electoral arena, and later in the Executive and, in the Senate. Considering Downs (1957), Dahl (1971), and Hofferbert and Budge (1992) statements, we have investigated the following hypothesis:

H2: A party's positions on a treaty tend to be congruent among different political arenas.

\section{Data and Methods}

We analyzed data extracted from documentary sources for the analysis of the positions of political parties on international human rights treaties in each of the arenas of party competition (Electoral, Executive, and Legislative).

In the case of the Electoral arena, documentary sources are the presidential campaign manifestos of the Democratic and Republican parties in the 1992, 1996, 2000, 2004, 2008, 2008, 2012, and 2016 elections. Campaign manifestos are presented by the parties during their conventions to select their respective candidates for the post of President of the United States. Manifestos aim to present public policy objectives and proposals, which are typically very broad and generic, although some sections may be written narrowly to appeal to partisan interest groups.

For analyzing the positions of the parties in the Executive, the data were collected in the two main public documents that guide US foreign policy. These are the National Security Strategy (NSS), edited by the National Security Council, and the Strategic Plan for International Affairs edited by the Department of State and USAID.

The National Security Strategy obligation goes back to the 1986 passage of the Goldwater-Nichols Department of Defense Reorganization Act. As a key statement on the President's global agenda, the national security report represents the cornerstone of the strategic direction of encom- 
5. Roll-call votes are not always required. Roll call votes occur when a representative or senator votes "yea" or "nay," so that the names of members voting on each side are recorded. On the other hand, senators can also vote by voice. A voice vote is a vote in which those in favor or against a measure say "yea" or "nay," respectively, without the names or tallies of members voting on each side being recorded.

6. Treaties approved in the Legislative like the Abolition of Forced Labour Convention (ILO), the International Covenant on Civil and Political Rights (UN), and the Convention against Torture and Other Cruel, Inhuman or Degrading Treatment or Punishment (UN) did not meet the two arenas criteria and were not included in the analysis. passing the allocation of national resources and the uses of elements of national power to protect the national interest and to achieve national and global goals and objectives of the United States. According to Reilly (2004), as a unifying document for the Executive Branch, the security strategy is designed to create an internal consensus on the foreign strategy of defense, diplomacy, and economics. In the scope of this article, we analyze the NSS's published during the administrations of Bill Clinton (1994, 1995, 1996, 1997, 1998, 1999, 2000), George W. Bush (2002, 2006), and Barack Obama $(2010,2015)$. The NSS should be transmitted annually since 1987, but frequently reports come in late or not at all for the decision of the Administration.

In turn, the Strategic Plan of the Department of State and USAID meets the provisions of the Government Performance and Results Act, passed by Congress in 1993. Along with the National Security Strategy, the Strategic Plan of the Department of State confirms several important guidelines of US foreign policy. The difference between the documents lies in the fact that the former articulates the priorities of the Administration in terms of policies and instruments dealing with security threats, while the latter sets out a global and systematic view of national interests, as well as covering the range of goals and activities of US government agencies abroad (DEPARTMENT OF STATE, 1999). We analyzed the four Strategic Plans edited by the governments of Clinton (1999), Bush (2003 and 2007), and Obama (2014).

Finally, we analyzed the positions of the parties in the Legislative Arena. In this case, there are three main sources of data: 1) Committee on Foreign Relations Reports on the treaties; 2) The Congressional Record of the floor actions; and 3) Treaties' roll call votes when available ${ }^{5}$.

\section{Case Selection}

According to the Office of the United Nations High Commissioner for Human Rights (OHCHR), there are 9 core international human rights conventions since the United Nations (UN) foundation. There are three possible positions for a state regarding a treaty: state party, signatory, or no action. Consent, via ratification, accession, or succession, followed by its enforcement is required for a state to be a 'state party' to a treaty. A preliminary endorsement and intent to domestic examination or ratification are required for a state to be considered a 'signatory' to a treaty, while 'no action' means that consent has not been expressed.

The United States has ratified until today only three of the nine UN human rights treaties. Americans have also ratified two ILO (International Labour Organization) and one $\mathrm{HCCH}$ (Hague Conference on Private International Law) human rights treaties, all after the end of the Cold War. Not all human rights treaties are included in our analysis though. To verify the possibility of congruence in the positions of the parties requires that a comparison is made between positions manifested in two or more arenas. Thus, the criterion of case selection was to identify positions manifested by parties over a human rights treaty in more than one arena ${ }^{6}$. We follow a sequential strategy. First, we identified the positions 
that the parties have expressed about human rights treaties in the Electoral Arena. Then, in the Executive, and finally in the Legislative, between 1992 and 2016.

There are cases where positions have been manifested by the parties: a) in the three arenas; b) only in the Electoral arena and in the Legislative arena; c) only in the Executive arena and in the Legislative arena, as shown below:

\section{Image 1 - Case Selection Criteria}

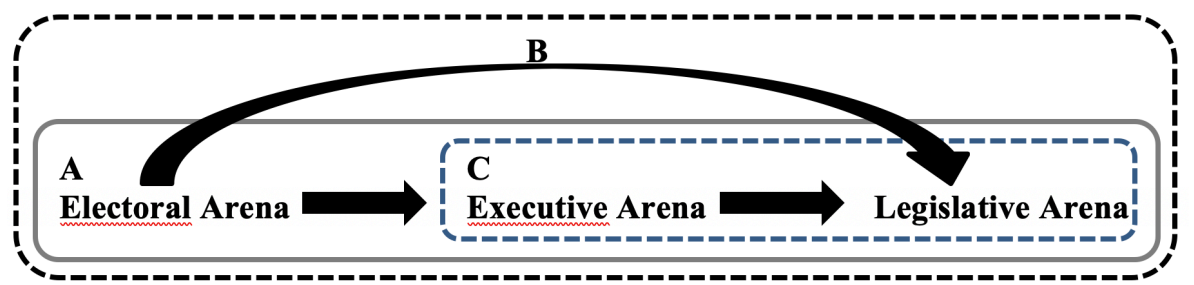

Source: Authors' elaboration.

Once the positions expressed by the parties on treaties in more than one arena have been identified, we excluded from the sample the generic positions that did not refer to a particular treaty. In this sense, the database was configured only by treaties specified in the party positions. The following treaties met the criteria:

\section{Chart 2 - Current Status of Human Rights Treaties}

\begin{tabular}{|l|l|l|l|l|l|}
\hline Treaty & Organization & Signed & $\begin{array}{l}\text { Received in the } \\
\text { Senate }\end{array}$ & Senate's last action & Ratified \\
\hline $\begin{array}{l}\text { International Convention on the } \\
\text { Elimination of All Forms of Racial } \\
\text { Discrimination }\end{array}$ & United Nations & $\begin{array}{l}\text { September 28, } \\
1966\end{array}$ & $\begin{array}{l}\text { February 23, } \\
1978\end{array}$ & $\begin{array}{l}\text { June 24, 1994 } \\
\text { Resolution of advice and consent to } \\
\text { ratification agreed to in Senate by } \\
\text { Division Vote. }\end{array}$ & $\begin{array}{l}\text { Yes, } \\
\text { October 21, } \\
1994\end{array}$ \\
\hline $\begin{array}{l}\text { Convention on the Elimination } \\
\text { of all Forms of Discrimination } \\
\text { Against Women }\end{array}$ & United Nations & July 17, 1980 & $\begin{array}{l}\text { November 12, } \\
1980\end{array}$ & $\begin{array}{l}\text { November 20, 2002 } \\
\text { Automatically referred to the CFR under } \\
\text { the provisions of Rule XXX, section 2, of } \\
\text { the Standing Rules of the Senate. }\end{array}$ & No \\
\hline $\begin{array}{l}\text { Hague Convention on Protection } \\
\text { of Children and Co-operation in } \\
\text { Respect of Intercountry Adoption }\end{array}$ & $\begin{array}{l}\text { Hague Conference } \\
\text { on Private Interna- } \\
\text { tional Law }\end{array}$ & March 31, 1994 & June 11, 1998 & $\begin{array}{l}\text { September 20, 2000 } \\
\text { Resolution of advice and consent to } \\
\text { ratification agreed to in Senate by } \\
\text { Division Vote. }\end{array}$ & $\begin{array}{l}\text { Yes, } \\
\text { December 12, } \\
2007\end{array}$ \\
\hline $\begin{array}{l}\text { Convention on the Rights of the } \\
\text { Child }\end{array}$ & United Nations \\
\hline $\begin{array}{l}\text { Convention concerning the } \\
\text { Prohibition and Immediate Action } \\
\text { for the Elimination of the Worst } \\
\text { Forms of Child Labour }\end{array}$ & $\begin{array}{l}\text { International La- } \\
\text { bour Organization }\end{array}$ & June 17, 1999 & May 8, 1999 & $\begin{array}{l}\text { Resuary 16, } \\
\text { ratification agreed to in Senate by } \\
\text { Division vote. }\end{array}$ & $\begin{array}{l}\text { Not sent } \\
\text { Not Applied }\end{array}$ \\
\hline $\begin{array}{l}\text { Convention on the Rights of } \\
\text { Persons with Disabilities }\end{array}$ & United Nations & July 30, 2009 & May 17, 2012 & $\begin{array}{l}\text { December 17, 2014 } \\
\text { Automatically referred to the CFR under } \\
\text { the provisions of Rule XXX, section 2, of } \\
\text { the Standing Rules of the Senate. }\end{array}$ & No \\
\hline
\end{tabular}

Source: Elaborated by the authors with data from the U.S. Congress and the United Nations Humans Right Indicators. Available at: http://www.congress.gov/ and https:// indicators.ohchr.org. 


\section{Methodology}

In addition to making an analysis between and among the selected cases of both parties in three different arenas, it is necessary to point out that it will also be done among a few cases (small-N). This method, called a case-oriented approach, allows the description of more details and the understanding of complex relationships, considering historical, institutional, and cultural particularities, focusing on specific processes and relationships (DELLA PORTA, 2008).

The comparative method fits the search given your goals. For Mahoney (2007), the comparative analysis can be used for the development and test of theories. Here, the second use is made, in which we use cross-case analysis as a means of causal inference, providing information about its context or mechanism. In it, hypotheses are evaluated by elucidating intervening processes and observable implications of arguments, requiring the use of various facts and knowledge of general causal principles to explain effects.

This method is used to locate intervening mechanisms by linking a hypothetical explanatory variable to a result, avoiding spurious correlations for a causal relationship. By identifying mechanisms that link a supposed explanatory variable and an effect variable, trust in the causal relationship is increased. More importantly, it must be understood that the comparative method is always contextual, which means that different variables can have similar effects, whereas similar variables can have different effects, depending on the context (RAGIN, 2000). In this way, it is necessary to examine differences and similarities in context to identify different causal combinations.

According to Ragin (2000), such a method identifies complex causal combinations that explain the occurrence of a multicausal phenomenon - which cannot be fully explained by quantitative measurements of the variables. It adopts the same logic of the statistical method but adapts the use of many variables with a small number of cases (small-N).

\section{Findings}

The willingness of the United States to ratify such treaties seems less than the willingness of many of the countries that the Americans are pressing to adhere to more humanitarian practices. On the other hand, there is no guarantee that the accession of repressive states to human rights treaties will lead them to comply with the agreed provisions.

Hafner-Burton et al.'s (2008) study show that nation-states with very negative human rights records tend to sign and ratify human rights treaties at similar rates to those states with positive records. In this respect, the most autonomous states among the repressive states stand out. This would occur because, being less constrained by domestic forces, these governments would be more likely to ratify human rights treaties as a symbolic commitment. Besides, the authors argue that the deepening of international human rights regimes creates opportunities for repressive states to exhibit low-cost legitimation commitments to world standards, 
leading them to ratify treaties even without the capacity or willingness to fulfill commitments.

In turn, the decisions of states to commit themselves and their willingness to comply with human rights treaties would be related to the level of democratization of the institutions of those states. Thus, Zhou's (2014) study suggests that political democratization is crucial to the creation of the international human rights regime because it creates "compromise" and "concession" mechanisms that motivate states to support such treaties.

Earlier, Hathaway's study (2007) already showed that states with less democratic institutions would be less likely to commit to human rights treaties if they had poor human rights records because there would be little prospect that treaties would be fulfilled. On the other hand, states with more democratic institutions would be less likely to commit to human rights treaties if they had precarious human rights records precisely because treaties would likely lead to behavioral changes.

Although adherence to human rights treaties is not related to the provision of compliance with these treaties, and that this provision varies according to the level of democratization of the institutions of those countries, the discussion about the United States' difficulty in ratifying such treaties is not less relevant. The main human rights treaties only began to be ratified by the United States in the late 1980s, and in those cases, they were ratified under reservations (RUDs). Also, important treaties such as the Convention on the Elimination of All Forms of Discrimination Against Women, the Convention on the Rights of Persons with Disabilities, and the Convention on the Rights of the Child have not been ratified yet. We begin our analysis from these cases.

\section{The Convention on the Elimination of all Forms of Discrimination Against Women}

The Convention on the Elimination of all Forms of Discrimination Against Women (CEDAW) is awaiting approval since it was sent by President Carter (Democratic Party) to the Senate for advice and consent in 1980. The hearings were not made by the Senate's Foreign Relations Committee until 1988. According to the 2002 Committee Report, both Reagan (1981-1989) and Bush (1989-1993), Republican administrations did not indicate support for ratification of the treaty, this being the reason for the FRC's failure to act on CEDAW in the period. However, in 1994, under Clinton's presidency, with a Democratic majority in the Senate, the treaty was nearing approval. By 13 votes to 5 (all 5 being from the Republican minority), the Senate Foreign Relations Committee recommended ratification of the treaty, subject to four reservations, four understandings, and two declarations. However, the midterm elections of 1994 led to the Republican takeover. Thus, the FRC came to be chaired by Republican Senator Jesse Helms, who did not take CEDAW to the floor. In 2002, Democrats retook the FRC, chaired by Senator Joseph Biden and new hearings were held. A new report was approved by the Committee by 12 votes (10 Democrats and 2 Republicans) to 7 (all 7 Republicans), but 
again CEDAW did not reach the floor. In the Report prepared by Senator Biden the reasons for its approval are manifested:

\begin{abstract}
Although women in the United States enjoy equal opportunity and equal protection of the law, these rights are not universally guaranteed elsewhere. The Convention provides an important means to advance these rights. The Committee believes that U.S. ratification of CEDAW will serve several important purposes (US SENATE, 2002b, p.5)
\end{abstract}

On the other hand, the Republican minority at the FRC in 2002 argued that "the Convention raises several complex and important issues which should have been explored further in one or more hearings with the current Administration's witnesses" (US SENATE, 2002b, p. 16). Moreover, they reinforced the position manifested by the Republican minority of 1994, sustaining that "the United States has the strongest record on opportunities and rights for women in the world, and that ratification of the Convention, rather than improving that record, would raise divisive social issues such as those noted above" (US SENATE, 2002b, p. 16).

The unwillingness of Republicans to CEDAW is also evident in the Executive Arena. In the foreign policy documents analyzed, Republicans failed to issue positions on the treaty. Democrats, in turn, positioned favorably to CEDAW in all seven National Security Strategy issued by the National Security Council of the Clinton Administration, between 1994 and 2000. They argued that the United States "must continue to demonstrate its willingness to adhere to international human rights standards" (THE WHITE HOUSE, 1997, p. 24) and they called for the Senate consent to ratify it (THE WHITE HOUSE, 1994; 1995; 1996; 1998; 1999; 2000). Thus, while the Republican chairman in the FRC refused to take action on CEDAW between 1995 and 2001, the Executive, under Democratic control, pressed annually for its ratification.

Besides, the lack of convergence between Democrats and Republicans on CEDAW was also manifested in the Electoral arena, from the 2000 election onwards. Democrats expressed favorably to the treaty in their manifestos, defending they were committed to ensuring full equality for women (DEMOCRATIC PARTY, 2008; 2012; 2016). Specifically, in the 2000 election manifesto, they stood to "make a special effort to hear women when they rise courageously to resist or end the war in their communities" (DEMOCRATIC PARTY, 2000, p. 49). In 2016, they related economic growth, decreases in poverty, and prosperity of the families and communities to the opportunity of women and girls being "healthy, educated, and able to participate economically” (DEMOCRATIC PARTY, 2016, p. 46).

On the other hand, Republicans stood in opposition to CEDAW in the Electoral Arena. The position taken by Republicans in campaign manifestos was that the United States should reject treaties, as CEDAW, because its long-range implications on the American family are ominous and unclear (REPUBLICAN PARTY, 2008; 2012; 2016). Devoting more attention to the treaty in the 2008 election, Republicans argue that "UN has no mandate to promote radical social engineering, any effort to address global social problems must respect the fundamental institutions of marriage and family" (REPUBLICAN PARTY, 2008, p. 7). Moreover, they supported the Mexico City policy, "which prohibits federal monies from 
being given to non-governmental organizations that provide abortions or actively promote abortion as a method of family planning in other countries" (REPUBLICAN PARTY, 2008, p. 7).

Indeed, the favorable position of the Democrats was congruent among Legislative, Executive, and Electoral arenas. For its part, the anti-treaty position expressed by the Republicans was congruent between Electoral and Legislative arenas. The inaction of Republican presidents on CEDAW may indicate that they were disinterested in the treaty's approval. In this sense, Republican positions would be also congruent with the Executive.

\title{
Convention on the Rights of Persons with Disabilities
}

The Convention on the Rights of Persons with Disabilities (CRPD) was signed by President Obama (Democratic Party) in July 2009. However, it has not been ratified yet. Obama transmitted the CRPD to the Senate for advice and consent to ratification in May 2012. On July 26, 20112, FRC, chaired by the Democrat Senator John Kerry, passed a Report on CRPD by a 13-6 vote, subject to certain conditions. All the ten Democrats present voted favorably. Republicans split 6 to 3 against the treaty. Democrats position on the treaty is expressed in the comments in the Committee Report:

\begin{abstract}
The committee is persuaded by the support of experts in disability law and advocacy that ratification of the Convention will enable the United States to more effectively advocate on behalf of the millions of disabled Americans. These experts indicate that it will give the United States a more effective voice in advocating for standards and practices abroad that comport with the high standards for the protection of disabled persons found in U.S. domestic law and practice. In addition to our bilateral efforts, ratification will allow the U.S. to nominate U.S. disabilities experts to sit on the Disabilities Committee, giving the United States a formal voice and vote in the Assembly of States Parties to the Convention (US SENATE, 2012, p.7)
\end{abstract}

Since this Report was approved, CRPD proceeded to the floor where despite senators voted favorably by $61-38$, it did not reach the required majority of $2 / 3$. Democrats voted unanimously favorably by $53-0$, while the majority among the (38-8) Republicans voted against it. Besides being rejected, Senate Majority Leader Harry Reid pledged to try to ratify the CRPD again. Senate FRC then held new hearings on the CRPD and approved a resolution, by 12-6, of advice and consent to ratification of the treaty. Again, 10 Democrats in FRC voted favorably. Republicans split from 6-2, against the CRPD. However, the treaty was not brought to the Senate floor for a vote and returned to the FRC at the end of the 113th Congress. The Republican position on the treaty was manifested in the minority views of the Committee Report:

It is one of our core values, and it is in our national interest to promote respect for every human life (...) While this treaty is not an appropriate vehicle for achieving these goals, principally because it has the potential to significantly alter the Constitution and because it is not an appropriate tool for establishing domestic policy, substantial concrete action will be needed to bring about actual and tangible progress internationally. And the United States should continue to bolster those efforts (US SENATE, 2014, p. 36) 
Republicans also manifested concerns on the impact of CRPD on Federalism and highlighted the implications of the provision of health care in the treaty, specifically regarding the phrase "sexual and reproductive health", which could include abortion once "no language defining sexual and reproductive health has been placed in the present resolution". As a highly controversial issue, abortion "should be determined through domestic processes, not at an international level" (US SENATE, 2014, p. 33).

Neither W. Bush (Republican Party), during CRPD negotiations, nor Obama, after signing it, manifested positions on the treaty in the Executive foreign policy documents. On the other hand, in the Electoral arena, Democrats and Republicans took positions on the treaty. Democrats manifested favorably to the CRPD, standing that is the role of the United States, as the world leader, to protect the rights of people with disabilities. They promised "ensure there is sufficient funding to empower Americans with disabilities to succeed in school and beyond" (DEMOCRATIC PARTY, 2008, p. 49); to "protect and expand the right of Americans with disabilities to get the accommodations and support they need to live in integrated community settings" (DEMOCRATIC PARTY, 2016, p. 19); to "improve access to meaningful and gainful employment for people with disabilities" (DEMOCRATIC PARTY, 2016, p. 19) and to "provide tax relief to help the millions of families caring for aging relatives or family members with chronic illnesses or disabilities" (DEMOCRATIC PARTY, 2016, p. 19). Republicans, in turn, opposed CRPD ratification, sustaining the same argument they used to criticize CEDAW, namely, by considering its long-range impact on the American family as ominous and unclear (REPUBLICAN PARTY, 2012; 2016).

Once again, the positions of both the Democratic and Republican Party were congruent, but not convergent, between the Legislative and Electoral Arenas. Democratic Party positions were also congruent with President Obama's signing of the treaty in the Executive. While Democrats stood for the ratification of the CRPD, Republicans opposed it.

\section{Convention on the Rights of the Child}

The Convention on the Rights of the Child (CRC) was signed by President Clinton in February 1995, but he did not submit it to the Senate, primarily because of strong opposition from the Legislative members. Bush Administration (2001-2009) opposed the treaty and expressed serious political and legal concerns to the CRC. Therefore, instead of pressing the Senate for its advice and consent on the Convention, the Bush Administration focused to get the Senate's approval on two Optional Protocols related to the CRC. The first is the Optional Protocol on the Involvement of Children in Armed Conflict; and the second is the Optional Protocol on the Sale of Children, Child Prostitution, and Child Pornography as shown in the chart below. 
Chart 3 - Current Status of the Optional Protocols to the CRC

\begin{tabular}{|c|c|c|c|c|}
\hline Treaty & Signed & Received in the Senate & Senate's last action & Ratified \\
\hline \multirow{2}{*}{$\begin{array}{l}\text { Optional Protocols to the } \\
\text { Convention on the Rights of } \\
\text { the Child }\end{array}$} & \multirow[b]{2}{*}{ July 5,2000} & \multirow[b]{2}{*}{ July 25,2000} & $\begin{array}{l}\text { June } 18,2002 \\
\text { (on Involvement of Children in Armed Conflict) } \\
\text { Resolution of advice and consent to ratification agreed to } \\
\text { in the Senate by Division Vote. }\end{array}$ & \multirow{2}{*}{$\begin{array}{l}\text { Yes, } \\
\text { December 23, } \\
2002\end{array}$} \\
\hline & & & $\begin{array}{l}\text { June 18, } 2002 \\
\text { (on the Sale of Children, Child Prostitution and Child } \\
\text { Pornography) } \\
\text { Resolution of advice and consent to ratification agreed to } \\
\text { in the Senate by Division Vote. }\end{array}$ & \\
\hline
\end{tabular}

Source: Elaborated by the authors with data from the U.S. Congress. Available at:

http://www.congress.gov/

These Protocols were considered less controversial than the Convention itself and they were sent to the Senate by President Clinton on July 25, 2000. After holding a public hearing on the Protocols on March 7, 2002, the FRC considered them favorably on May 23, 2002, by voice vote, recommending Senate's advice and consent to them. Considered on the floor, both Protocols got Senate's approval on a Division vote. Once the roll call was not requested, it was not possible to identify the minority who opposed the Protocols. Moreover, only senators who supported the Protocols were addressed on the floor. According to Democratic Senator Barbara Boxer, the formal adoption of the protocol's standards for U.S. military operations would "enable the U.S. to be able to effectively pressure other governments and forces to end the use of children within their military ranks" CONGRESSIONAL RECORD, 2002, p. S5717). About the second Protocol, she stated that ratification was important to protect vulnerable children, who "cannot often get help on their own - not only because of their young age- but also because they have no birth certificates or official documents. They are, in effect, "invisible."' (CONGRESSIONAL RECORD, 2002, p. S5718).

Parties in the Executive and the Electoral arena, on the other hand, manifested positions about the Convention itself and not about its Protocols voted in the Legislative. Precisely, the Democratic Party showed support to the CRC and the Republican Party opposed it. However, while Democrats took positions only in the Executive arena, Republicans manifested on CRC only in the Electoral Arena. Democrats highlighted that President Clinton after signing CRC was seeking consent from the Senate on it. The reason for support was to demonstrate the United States' "willingness to adhere to international human rights standards" (THE WHITE HOUSE, 1996, p. 33; 1997, p. 24). On the other hand, Republicans used the Electoral arena to manifest their opposition to the CRC. By arguing that under the US Constitution, "treaties become the law of the land", they justified their opposition on the same grounds they did on CEDAW and CRPD. Precisely, because of the unclear implications of treaties, like the CRC, on the American family (REPUBLICAN PARTY, 2008; 2012; 2016).

Therefore, convergence was possible only on the Optional Protocols to CRC in the Legislative Arena. Positions of Democrats in the 
7. The United States did not ratify CERD as a self-executing treaty, asserting that CERD did not create an independent cause of action in U.S. courts. They claimed that because its laws provided extensive protections and remedies against racial discrimination, it did not need to enact additional legislation to comply with CERD.

8. The proviso of Senator Helms clarifies the relationship between the convention and the U.S. Constitution. Since this relationship is a matter of U.S. domestic law, the proviso was not included in the instrument of ratification deposited by the President.
Executive and of the Republicans in the Electoral arena show divergence on CRC itself. This divergence prevented Clinton from submitting the Convention to the Senate. While the Democratic position is congruent between the CRC (in the Executive) and its optional protocols (in the Legislative), the Republican position diverges between the CRC (in the Electoral) and its protocols (in the Legislative).

\section{International Convention on the Elimination of All Forms of Racial Discrimination}

The International Convention on the Elimination of All Forms of Racial Discrimination (CERD) received its advice and consent from Senate on June 24,1994 , and it was ratified under reservations ${ }^{7}$ by President Clinton on October 21, 1994. Despite ratification, building convergence around the treaty was a time-consuming process. Signed by Democrat President Lyndon Johnson in 1966, CERD would only be referred to the Senate in 1978 by President Carter. From then on, it was 16 years before the treaty was approved by the Senate, although under RUDs. According to the Committee Report, domestic and international events at the end of 1979 prevented FRC from moving to a vote on the Convention. After that, neither the Reagan nor the Bush Administration supported ratification (US SENATE, 1994). President Clinton's support for CERD unlocked the treaty procedure in the FRC. Hearings were held in May 1994 which followed the unanimous approval of an amendment by Republican Senator Jesse Helms to the motion for a resolution but not to the instrument of ratification ${ }^{8}$. Subsequently, the resolution of ratification was unanimously approved, by voice vote, by the members of the FRC. Proceeded to the floor, CERD passed with the majority required. A minority of senators voted against it. Even though it is not possible to identify them since there was no request for a nominal vote. On the floor, the Democratic Senator and Chairman of the FRC, Claiborne Pell stated on the Treaty:

\footnotetext{
The convention is an important instrument in the international community's struggle to eliminate racial and ethnic discrimination. As a nation that has gone through its struggle to overcome segregation and discrimination, we are in a unique position to lead the international effort. Our position and the credibility of our leadership will be strengthened immeasurably by the ratification of this convention--ratification, I might add, that is long overdue. Moreover, ratification will also enable the United States to participate in the work of the Committee on the Elimination of Racial Discrimination established by the convention to monitor compliance (CONGRESSIONAL RECORD, 1994, p. S7635).
}

Once different positions on CERD were not recorded on the floor, convergence between Democrats and Republicans seems to have prevailed in the Legislative Arena. In the Executive arena, in turn, only the Democratic Party manifested on CERD. In the National Security Strategy, the Clinton Administration argued that the ratification of CERD demonstrated "our own willingness to adhere to international human rights standards" (THE WHITE HOUSE, 1994, p. 20; 1995, p. 24; 1996, p. 33). However, in the Electoral Arena were not manifested positions of both parties on the treaty. Thus, the Democratic position on CERD is congruent between the Executive and Legislative arenas. The lack of ac- 
tion of Republican Administrations in the Executive on CERD contrasts with the Republican acceptance of the treaty in the Legislative. Ultimately, this could indicate an incongruity by the Republican Party. However, this was not the case. Republicans' convergence with Democrats in Congress came only after decades of gridlock and negotiations that assured, through RUDs, that CEDAW would not be self-executing.

\section{Convention concerning the Prohibition and Immediate Action for the} Elimination of the Worst Forms of Child Labour

The Convention for the Elimination of the Worst Forms of Child Labour (ILO) received Senate's advice and consent on May 11, 1999, and it was ratified by President Clinton on December 2, 1999. This rapid process is due, according to the FRC Chairman, Republican Senator Jesse Hel$\mathrm{ms}$, to treaty negotiators who "consulted regularly with members of this committee and the committee staff during negotiations and were able to ensure that the treaty tracked consistently with the United States Fair Labor Standards Act”" (US SENATE, 1999, p. 9).

After holding a public hearing, the FRC voted favorably on ILO, by voice vote, on November 3, 1999. The Committee Report stated the "proposed Convention is in the interest of the United States" (US SENATE, 1999, p. 5). However, the recommendation for consent included RUDs? Moved to the floor, the treaty got Senate's approval by Division vote (CONGRESSIONAL RECORD, 1999, p. S14226).

In the Executive, only the Democratic Party took positions on the ILO treaty. They promised to work "to ensure that international human rights principles protect the most vulnerable or traditionally oppressed groups in the world - women, children, indigenous people, workers, refugees, and other persecuted persons" (THE WHITE HOUSE, 1999, p. $47 ; 2000$, p. 47). To fulfill this end they expressed support for the wide ratification of the ILO Convention on the Worst Forms of Child Labor (THE WHITE HOUSE, 1999; 2000). No positions about the Convention were taken in the Electoral arena. Thus, while parties were convergent in the Legislative on the ILO treaty, the Democratic Party was also congruent about its positions in the Executive and the Legislative.

\section{Hague Convention on Protection of Children and Co-operation in Respect of Intercountry Adoption}

Signed by President Clinton on March 31, 1994, the Hague Adoption Convention was ratified by President Bush on December 12, 2007. The Republican takeover of 1994 in the Senate and the election of George W. Bush in 2000 contributed to the 13-year delay between the signing and the ratification of the Hague Convention. Clinton transmitted the Convention to the Senate only on June 11, 1998. CFR held a public hearing on the treaty in 1999; and, on April 13,2000, the Committee finally approved the proposed convention, by voice vote. Republican Senator Sam Brownback was the only one to oppose the treaty. The Convention, then, proceeded to the floor. Together with the Convention, Senator Enzi asked
9. The United States declared the Senate's advice and consent should be binding on the President's interpretation of the Treaty; on a proviso of the supremacy of its Constitution; on two understandings about basic education and children working on farms. 
10. Biden specifically mentioned the efforts of the Democratic Senator Landrieu, himself, and the Democratic Representatives Sam Gejdenson and Bill Delahunt; and also the efforts of Republican senators Helms (Chairman of FRC) and Brownback, and of the Republican representatives Ben Gilman and Dave Camp. unanimous consent to the Implementation Act of the Hague Adoption Convention (H.R. 2909), already agreed in the House. Senators then, gave their advice and consent to the Convention on September 20, 2000, with declarations. A Division vote was requested and senators were counted. A majority of two-thirds of senators voted favorably. Democratic Senator John Biden stated on the occasion:

\begin{abstract}
This treaty is important for a very simple reason - it will help facilitate international adoptions and provide important safeguards for children and adoptive parents. It is a good thing when the government can make things easier for its citizens - in this case, adoptive parents. Adoption is a joyous occasion, but the current system can be confusing and present uncertainties (CONGRESSIONAL REPORT, 2000, p. S8866).
\end{abstract}

To express the convergence regarding the Adoption Convention and its implementation, Senator Biden highlighted it was the product of compromise between Republicans and Democrats in both Senate and House ${ }^{10}$ : "None of us got all that we wanted. But I believe we have a good product here. I want to express my appreciation to them and their staff for the hard work that went into the drafting of this bill" (CONGRESSIONAL REPORT, 2000, p. S8866).

In the Executive arena, only the Republican Party took positions on the Hague Convention. In the Strategic Plan of 2003, it was stated that the Administration would "push for implementation of The Hague Intercountry Adoption Convention" (DEPARTMENT OF STATE, 2003, p. 17). In the same document, in 2007 , they added the Department of State would "work tirelessly to prevent and resolve cases of international parental child abduction". (DEPARTMENT OF STATE, 2007, p. 39). Moreover, none of the parties manifested on the Hague Convention in the Electoral Arena. Therefore, party positions on the treaty were convergent in the Legislative and the Republican position is congruent between the Executive and the Legislative.

\section{Discussion}

An examination of the ratification process of international human rights treaties reveals a trend that may be linked to party positions. In all the six cases analyzed, the treaties were signed by a Democrat President. Except for the CRC, which did not reach the Legislature, all treaties were also sent to the Senate by a Democrat President. Bill Clinton ratified two treaties and George W. Bush, in turn, ratified one treaty and the two Optional Protocols to the CRC. Indeed, the Clinton Administration has acted to follow up the treaties awaiting Senate approval, such as CERD and CEDAW, and has also negotiated and signed the Hague Adoption Convention, the ILO Convention on Worst Forms of Child Labor, and the CRC.

Given the strong performance of the Democrat Presidents and Clinton, in particular, for a greater commitment of the United States to human rights issues, in the late 1990s, authors have remarked that the United States would have raised priorities, which do not satisfy the American national interest. An example of this is the conduction of foreign 
policy by the president during the conflict with Yugoslavia, which made evident to the world the limit of American power, after having built a coalition to tackle the problem (GOW, 1997; JAKOBSEN, 1994; KRAHMANN, 2003). Understanding that national interest should focus primarily on security, Huntington (1997) argued that commercial and ethnic interests would prevail over other potentially more vital interests in the face of the United States' difficulty in defining its priorities after the end of the Cold War.

Based on Perry and Carter's (1999) categorization of US security risks where three priority lists are ranked, Joseph Nye Jr. (1999) discusses the prevalence of humanitarian priorities at the expense of vital priorities for the United States in the post-Cold War era. According to Nye, "List C" would have risen to the forefront of US foreign policy priorities because of the disappearance of vital threats after the end of the Cold War and because its capacity for attention in the mass media, which has an impact on public opinion and the formulation of foreign policy.

In a similar vein to Huntington (1997) and Nye (1999), then-foreign policy advisor George W. Bush, during the 2000 presidential campaign, Rice (2000) states that the national interest would have been replaced by humanitarian interests and interests of the international community under the Clinton administration, whose eagerness to find multilateral solutions to global problems would have resulted in the ratification of agreements that were not in US interests.

One common element among these analyzes is the suggestion that the American national interest would have been replaced by the defense of humanitarian interests in the United States in the Clinton Administration, to the detriment of more important issues such as national security. Critically, these analyses link human rights issues to the Democrat President. Indeed, human rights advocacy has been on the Democratic Party's agenda since before the end of the Cold War. Precisely, the defense of human rights by the Democrats goes back to the erosion of the liberal-conservative consensus that prevailed until the Vietnam War. In that sense, Jimmy Carter, during his presidency, sought a new direction for American foreign policy. This would be shaped by principles of human rights and non-intervention. According to Schmitz and Walker (2004, p. 114), "in making human rights a key element of all discussions and considerations of American foreign policy, Carter succeeded in shifting the discourse on American foreign policy away from the dominant concerns of the Cold War and containment".

In contrast to the Democratic movement for the defense of human rights, in the mid-1970s Republicans received the support of Christian fundamentalists, pro-life groups, and others of special interest on the right. In the early 1980s, "news stories about abortion indicated that pro-life interest groups were associated with the Republican Party while pro-choice groups were aligned with the Democratic Party, underscoring the clearer and more differentiated positions being adopted by the parties" (CARMINES et al, 2010, p. 1152). Since then, the "Republican Party and conservative religious activists have presented themselves as protectors of moral and religious values" (WILLIAMS, 2007, p. 1), addressing 
"policies relating to sexual behavior, marriage, and the family, including opposition to abortion and same-sex marriage" (WILLIAMS, 2007, p. 1).

Indeed, the Republican opposition to CEDAW, CRPD, and CRC was founded, as we have seen, in the defense of principles related to traditional morality, which are ideologically associated with conservative thinking and positioning right. It is important to note, however, that Republicans are not opposed only to human rights treaties, but to all treaties that may challenge American sovereignty. Such perception appears in the Republican campaign manifestos of 1996, 2012, and 2016: "Just as George Washington wisely warned America to avoid foreign entanglements and enter into only temporary alliances, we oppose the adoption or ratification of international treaties that weaken or encroach upon American sovereignty" (REPUBLICAN PARTY, 2012, p. 14).

In this sense, besides the ideological dimension, there would also be an isolationist perspective in the Republican opposition. In this regard, although the election of the Republican Dwight Eisenhower has driven a conservative internationalist orientation of the Republican Party in foreign policy since the 1950s (ROSATI; SCOTT, 2011), especially concerning the struggle against communism, the isolationist perspective never would have been abandoned, being invoked in matters involving sovereignty, as is the case of international treaties. In contrast, the Democrats have been historically characterized by the defense of a liberal internationalist orientation in foreign policy.

Indeed, these differences in the perspective of foreign policy that characterize the parties and the congruence they manifest in their positions on human rights treaties in the different arenas challenge the continuity in American national interests and thus affect the country's commitment to human rights demands. Because of the lack of consensus, American exceptionalism fed into rights rhetoric. Rights for Americans was one thing. US action on behalf of the human rights of foreigners was another (FORSYTHE, 1995).

Given the above, the analysis of the positions of Democrats and Republicans on human rights treaties in the Electoral, the Executive, and the Legislative arena supports the hypothesis that bipartisan convergence is affected by the ideological arguments that underpin the positions of the parties and also the hypothesis that a party's position on a treaty tends to be congruent among different arenas.

Conclusions

In verifying the positions of Democrats and Republicans regarding human rights treaties in the Electoral, Executive and Legislative arenas in the post-Cold War era, we concluded that the possibility of interpartisan convergence is affected by the ideological arguments that underpin the positions of the parties and, that there is congruence in the positions that the parties manifest in the different arenas.

Specifically, to convergence, we saw that it was not reached in three of the six cases analyzed. They are the Convention on the Elimination of All Forms of Discrimination Against Women (CEDAW), the Convention 
on the Rights of Persons with Disabilities (CRPD), and the Convention on the Rights of the Child (CRC). In the specific case of the CRC, although there was no convergence with the main Convention, the parties converged and made possible the approval in the Senate of the two Optional Protocols related to the CRC, considered less controversial.

We identified, in the positions of Democrats and Republicans, ideological arguments that grounded the party divergence in those three treaties. Precisely, the Republican opposition to CEDAW, CRPD, and CRC was based on the defense of principles linked to traditional morality, which are ideologically associated with conservative thinking and right-wing positioning. In turn, Democratic Party support for the treaties was based on the defense of individual rights of minorities, ideologically linked to liberal thinking and the realignment in American foreign policy initiated by Carter.

On the other hand, convergence was possible in the other three cases analyzed. They are the International Convention on the Elimination of All Forms of Racial Discrimination (CERD), the Hague Convention on Protection of Children and Co-operation in Respect of Intercountry Adoption, and the Convention Concerning Prohibition and Immediate Action for the Elimination of the Worst Forms of Child Labor (ILO). However, even in these cases, convergence between parties has not been easily achieved. In addition to being ratified with reservations, these treaties have taken some time to receive the consent of the Senate.

To the congruence of party positions among the Electoral, Executive and Legislative arenas, we have seen that it occurred in all cases analyzed, although in the Legislative there has not always been complete party unity around a treaty. Still, party majorities followed the same positions their parties expressed in the Executive and/or Electoral arena. This finding suggests that there is responsiveness in the positions advocated by Democrats and Republicans on human rights treaties and that this responsiveness is placed above a possible continuity of American national interests.

Thus, alternation in the Executive's command and majority control in the Senate has changed the commitment of the United States to human rights treaties. While the Democratic Party has positioned and acted to ratify human rights treaties, the Republican Party has been opposing or working to delay ratification of these treaties, which have taken place after much negotiation and with reservations.

Although the small number of cases analyzed does not allow us to make generalizations, the findings of this article offer clues to identify the reasons why important human rights treaties have not been ratified by the United States. The analysis of an expanded number of cases and other issues in future work may reinforce the understanding that continuity in American foreign policy is affected by party alternation in the Executive and by changes in the control of the Senate majority, and that these alternations suggest different approaches in foreign policy. That is, concerning international treaties, while the Democrats would be positioning themselves from a liberal internationalist approach, the Republicans, on the other hand, would be positioning themselves from a conservative isolationist perspective. 
References

ALDRICH, J. Why Parties? A Second Look. Chicago and London: University of Chicago Press, 2011.

BECKMANN, M.; MCGANN, A. Navigating the legislative divide: polarization, presidents, and policymaking in the United States. Journal of Theoretical Politics, v. 20, n. 2, p. 201-220, 2008.

BRADLEY, C. A. Unratified Treaties, Domestic Politics, and the U.S. Constitution. Harvard Journal of International Law, v. 48, p. 307-336, 2008.

BRUNELL, T. et al. Components of party polarization in the US House of Representatives. Journal of Theoretical Politics, June 9, p.1-27, 2015.

CARMINES, E. G. et al. How Abortion Became a Partisan Issue: Media Coverage of the Interest Group凹Political Party Connection. Politics \& Policy, v. 38, p. 1135-1158, 2010.

CARTER, A.; PERRY, W. Preventive Defense: A New Security Strategy for America. Washington: Brookings Institution Press, 1999.

COSER, L. The Functions of Social Conflict. New York: The Free Press, 1956.

DAHL, R. A. Polyarchy: participation and opposition. New Haven: Yale University Press, 1971.

DELLA PORTA, D. Comparative Analysis: Case-oriented versus Variable-oriented research. In: DELLA PORTA, D.; KEATING, M. (eds.), Approaches and methodologies in the social sciences: a pluralist perspective. Cambridge: Cambridge University Press, 2008.

DEUTSCH, K. Political Community and the North Atlantic Area: International Organization in the Light of Historical Experience. Princeton: Princeton University Press, 1957.

DOWNS, A. An economic theory of democracy. New York: Harper and Row, 1957.

ELSIG, M. et al. Who Is in Love with Multilateralism? Treaty Commitment in the Post-Cold War Era. European Union Politics, v. 12, n. 4, p. 529-50, 2011.

FLYNN, D.; HARBRIDGE, L. How Partisan Conflict in Congress Affects Public Opinion: Strategies, Outcomes, and Issue Differences. American Politics Research, v. 44, n. 5, p. 875-902, 2016.

FORSYTHE, D. P. Human Rights and US Foreign Policy: Two Levels, Two Worlds. Political Studies, v. 43, n. 1, p. 111-130, 1995.

GOLDSTEIN, J. et al. Introduction: Legalization and world politics. International Organization, v. 54, n.3, p. 385-399, 2000

GOW, J. Triumph of the Lack of Will: International Diplomacy and the Yugoslav War. London: Hurst, 1997.

HAAS, E. B. Beyond the nation-state: functionalism and international organization. Stanford: Stanford University Press, 1964

HACKER, J.S.; PIERSON, P. Off Center: The Republican Revolution and the Erosion of American Democracy. New Haven, CT: Yale University Press, 2006

HAFNER-BURTON, E. M. et al. International human rights law and the politics of legitimation. International Sociology Journal, v. 23, n. 1, p. 115-141, 2008.

HATHAWAY, O. Why Do Countries Commit to Human Rights Treaties? Journal of Conflict Resolution, v. 51, n. 4, p. 588-621, 2007

HOFFERBERT, R. I.; BUDGE, I. The Party Mandate and the Westminster Model: Election Programmes and Government Spending in Britain, 1945-1985. British Journal of Political Science, v. 22 , n. 2, p. 151-182, 1992

HUNTINGTON, S. P. The erosion of American national interests. Foreign Affairs, v. 76, n. 5 , p. 28-49, 1997

JAKOBSEN, V. Multilateralism Matters But How? The Impact of Multilateralism on the Great Power Policy Towards the Break-Up of Yugoslavia. San Domenico: EUI, 1994

KEOHANE, R. O.; NYE, J. S. Power, and Interdependence. New York: Little, Brown, 1977.

KRASNER, S. Structural causes, and regime consequences: Regimes as intervening variables. International Organization, v. 36, n. 2, p. 185-205, 1982.

KRAHMANN, E. Multilevel Networks in European Foreign Policy. Aldershot: Ashgate, 2003.

LAYMAN, G.; CARSEY, T. Party Polarization and 'Conflict Extension' in the American Electo- 
rate. American Journal of Political Science, v, 46, n. 4, p. 786-802, 2002.

LEVENDUSKY, M. The Partisan Sort: How Liberals Became Democrats and Conservatives Became Republicans. Chicago: University of Chicago Press, 2009.

LINDSAY, J. Congress and the Politics of US Foreign Policy. Baltimore: The Johns Hopkins University Press, 1994.

MAHONEY, J. Qualitative Methodology, and Comparative Politics. Comparative Political Studies, v. 40, n. 2, p. 122-144, 2007.

MAINWARING, S. EUA: a guinada à direita. Lua Nova, v. 3, n. 1, 1986.

MCCARTY, N; POOLE, K; ROSENTHAL, H. Income Redistribution and the Realignment of American Politics. Washington, DC: AEI Press, 1997.

MITRANY, D. A Working Peace System. Chicago: Quadrangle Press, 1966.

MILneR, H. V.; TINGLeY, D. American Foreign Policy, and Domestic Politics: Sailing the Water's Edge. Princeton, NJ: Princeton University Press, 2015.

MEERNIK, J. Presidential Support in Congress: Conflict and Consensus on Foreign and Defense Policy. The Journal of Politics, v. 55, n. 3, p. 569-587, 1993.

NELSON, M.; TILLMAN, T. The presidency, the bureaucracy, and foreign policy: Lessons from Cambodia. In: NELSON, M. (ed.) The presidency and the political system. Washington, DC: CQ Press, 1984.

NYE, J. S. Redefining the national interest. Foreign Affairs, v. 78, n. 4, p. 22-35, 1999.

ORNSTEIN, N. Foreign Policy, and the 1992 Election. Foreign Affairs, v. 71, n. 3, p. 01-16, 1992.

POOLE, K.; ROSENTHAL, H. Congress: A Political-Economic History of Roll Call Voting. New York: Oxford University Press, 1997.

POPE, J C.; WOON, J. Measuring Changes in American Party Reputations, 1939-2004. Political Research Quarterly, v. 62, n. 4, p. 653-661, 2008.

PUTNAM, R. Diplomacy, and domestic politics: The logic of two-level games. International Organization, v. 42, n. 3, p. 427-460, 1988.

RAGUSA, J. M. Partisan Cohorts, Polarization, and the Gingrich Senators. American Politics Research, v. 44, n. 2, p. 296-325, 2016.

RAGIN, C. C. Fuzzy Set Social Science. Chicago: University of Chicago Press, 2000.

REILLY, T. P. The National Security Strategy of the United States: Development of Grand Strategy. Strategy Research Project. Carlisle Barracks: U.S. Army War College, 2004.

RICE, C. Campaign 2000: Promoting the National Interest. Foreign Affairs, v. 79, n. 1, p. 45-62, 2000.

ROHDE, D. Parties, and leaders in the Postreform House. Chicago: University of Chicago Press, 1991.

ROSATI, J. A.; SCOTT, J. M. The Politics of United States Foreign Policy. Wadsworth: Thomson Learning, 2011.

ROSENAU, J.; CZEMPIEL, E. (Eds.) Governance without Government: Order and Change in World Politics. Cambridge: Cambridge University Press, 1992.

SCHMITZ, D. F.; WALKER, V. Jimmy Carter, and the Foreign Policy of Human Rights. Diplomatic History, v. 28, p. 113-143, 2004.

SCOTT, D. C. Presidential Power to "Un-sign" Treaties. The University of Chicago Law Review, v. 69, p. 1447-1477, 2002.

SIMMEL, G. The Sociology of Conflict: I. American Journal of Sociology, v. 9, n. 4, p. 490-525, 1904.

SNYDER, Jr., J.; GROSECLOSE, T. Estimating Party Influence in Congressional Roll-Call Voting. American Journal of Political Science, v. 44, n. 2, p. 193-211, 2000.

THERIAULT, S. Party Polarization in the US Congress Member Replacement and Member Adaptation. Party Politics, v. 12, n. 4, p. 483-503, 2006.

U.S. CONSTITUTION, art. II, $\S 2$.

WILLIAMS, G. I. The Democrats Embrace God: An Unqualified Blessing? Forum on Public Policy Online: A Journal of the Oxford Roundtable Summer, p. 1-29, 2007. 
ZHOU, M. Signaling Commitments, Making Concessions: Democratization and State Ratification of International Human Rights Treaties, 1966-2006. Rationality and Society, v. 26, n.4, p. 475-508, 2014.

\section{Data Sources}

Electoral Arena

DEMOCRATIC PARTY. 1992 Democratic Party Platform, July 13, 1992. Online by Gerhard Peters and John T. Woolley, The American Presidency Project. Available at: http://www.presidency.ucsb.edu/ws/?pid=29610. Accessed: 13 Mar. 2019

DEMOCRATIC PARTY. 1996 Democratic Party Platform, August 26, 1996. Online by Gerhard Peters and John T. Woolley, The American Presidency Project. Available at: http://www.presidency.ucsb.edu/ws/?pid=29611. Accessed: 13 Mar. 2019

DEMOCRATIC PARTY. 2000 Democratic Party Platform, August 14, 2000. Online by Gerhard Peters and John T. Woolley, The American Presidency Project. Available at: http:// www.presidency.ucsb.edu/ws/?pid=29612. Accessed: 13 Mar. 2019.

DEMOCRATIC PARTY. 2004 Democratic Party Platform, July 27, 2004. Online by Gerhard Peters and John T. Woolley, The American Presidency Project. Available at: http://www.presidency.ucsb.edu/ws/?pid=29613. Accessed: 13 Mar. 2019

DEMOCRATIC PARTY. 2008 Democratic Party Platform, August 25, 2008. Online by Gerhard Peters and John T. Woolley, The American Presidency Project. Available at: http://www.presidency.ucsb.edu/ws/?pid=78283. Accessed: 13 Mar. 2019.

DEMOCRATIC PARTY. 2012 Democratic Party Platform, September 3, 2012. Online by Gerhard Peters and John T. Woolley, The American Presidency Project. Available at: http:// www.presidency.ucsb.edu/ws/?pid=101962. Accessed: 13 Mar. 2019.

DEMOCRATIC PARTY. 2016 Democratic Party Platform, July 21, 2016. Online by Gerhard Peters and John T. Woolley, The American Presidency Project. Available at: http://www.presidency.ucsb.edu/ws/?pid=117717. Accessed: 13 Mar. 2019.

REPUBLICAN PARTY. Republican Party Platform of 1992, August 17, 1992. Online by Gerhard Peters and John T. Woolley, The American Presidency Project. Available at: http:// www.presidency.ucsb.edu/ws/?pid=25847. Accessed: 13 Mar. 2019 .

REPUBLICAN PARTY. Republican Party Platform of 1996, August 12, 1996. Online by Gerhard Peters and John T. Woolley, The American Presidency Project. Available at: http:// www.presidency.ucsb.edu/ws/?pid=25848. Accessed: 13 Mar. 2019.

REPUBLICAN PARTY. 2000 Republican Party Platform, July 31, 2000. Online by Gerhard Peters and John T. Woolley, The American Presidency Project. Available at: http://www.presidency.ucsb.edu/ws/?pid=25849. Accessed: 13 Mar. 2019 .

REPUBLICAN PARTY. 2004 Republican Party Platform, August 30, 2004. Online by Gerhard Peters and John T. Woolley, The American Presidency Project. Available at: http://www.presidency.ucsb.edu/ws/?pid=25850. Accessed: 13 Mar. 2019.

REPUBLICAN PARTY. 2008 Republican Party Platform, September 1, 2008. Online by Gerhard Peters and John T. Woolley, The American Presidency Project. Available at: http:// www.presidency.ucsb.edu/ws/?pid=78545. Accessed: 13 Mar. 2019.

REPUBLICAN PARTY. 2012 Republican Party Platform, August 27, 2012. Online by Gerhard Peters and John T. Woolley, The American Presidency Project. Available at: http://www.presidency.ucsb.edu/ws/?pid=101961. Accessed: 13 Mar. 2019.

REPUBLICAN PARTY. 2016 Republican Party Platform, July 18, 2016. Online by Gerhard Peters and John T. Woolley, The American Presidency Project. Available at: http://www.presidency.ucsb.edu/ws/?pid=117718. Accessed: 13 Mar. 2019.

Executive Arena

DEPARTMENT OF STATE. United States Strategic Plan for International Affairs. Washington, D.C.: Department of State, 1999.

DEPARTMENT OF STATE. The Department of State and Agency for International Development (USAID) Strategic Plan for Fiscal Years 2004 to 2009. Washington, D.C.: Department of State and USAID, 2003. 
DEPARTMENT OF STATE. The Department of State and Agency for International Development (USAID) Strategic Plan for Fiscal Years 2007 to 2012. Washington, D.C.: Department of State and USAID, 2007.

DEPARTMENT OF STATE. The Department of State and U.S. Agency for International Development (USAID) Strategic Plan for Fiscal Years 2014 to 2017. Washington, D.C.: Department of State and USAID, 2014.

THE WHITE HOUSE. A National Security Strategy of Engagement and Enlargement. Washington, D.C.: Department of Defense, 1994.

THE WHITE HOUSE. A National Security Strategy of Engagement and Enlargement. Washington, D.C.: Department of Defense, 1995.

THE WHITE HOUSE. A National Security Strategy of Engagement and Enlargement. Washington, D.C.: Department of Defense, 1996.

THE WHITE HOUSE. A National Security Strategy for a New Century. Washington, D.C.: Department of Defense, 1997.

THE WHITE HOUSE. A National Security Strategy for a New Century. Washington, D.C.: Department of Defense, 1998.

THE WHITE HOUSE. A National Security Strategy for a New Century. Washington, D.C.: Department of Defense, 1999.

THE WHITE HOUSE. A National Security Strategy for a Global Age. Washington, D.C.: Department of Defense, 2000.

THE WHITE HOUSE. The National Security Strategy of the United States of America. Washington, D.C.: Department of Defense, 2002.

THE WHITE HOUSE. The National Security Strategy of the United States of America. Washington, D.C.: Department of Defense, 2006.

THE WHITE HOUSE. National Security Strategy. Washington, D.C.: Department of Defense, 2010 .

THE WHITE HOUSE. National Security Strategy. Washington, D.C.: Department of Defense, 2015.

Legislative Arena

CONGRESSIONAL RECORD. "International Convention on the Elimination of All Forms of Racial Discrimination,” Senate Floor, June 24, 1994. Washington, DC, Senate, 103rd Congress, 2d Session, p.S7634-5, 1994.

CONGRESSIONAL RECORD. "Convention for Elimination of the Worst Forms of Child Labor,” Senate Floor, November 5, 1999, Washington, DC, Senate, 106th Congress, 1d Session, p.S14224-6, 1999.

CONGRESSIONAL RECORD. "Convention on the Protection of Children and Co-Operation in Respect of Intercountry Adoption,” Senate Floor, September 20, 2000, Washington, DC, Senate, 106th Congress, 1st Session, p.S8866-8, 2000.

CONGRESSIONAL RECORD. “The Optional Protocol to the Convention on the Rights of the Child on the Sale of Children, Child Prostitution and Child Pornography and The Optional Protocol to the Convention on the Rights of the Child on the Involvement of Children in Armed Conflict," Senate Floor, June 18, 2002. Washington, DC, Senate, 107th Congress, 2d Session, p.S5717-9, 2002.

CONGRESSIONAL RECORD. "Convention on the Rights of Persons with Disabilities," Senate Floor, December 4, 2012, Washington, DC, Senate, 112th Congress, 2d Session, p.S7365-S7379, 2012.

U.S. SENATE. Committee on Foreign Relations, "International Convention on the Elimination of All Forms of Racial Discrimination,” Report, June 2, 1994. Washington, DC, Government Printing Office (Senate Exec. Rept. 103-29, 103rd Congress, 2d Session), 1994.

U.S. SENATE. Committee on Foreign Relations, "Convention for Elimination of the Worst Forms of Child Labor,” Report, November 3, 1999. Washington, DC, Government Printing Office (Senate Exec. Rept. 106-12, 106th Congress, 1st Session), 1999.

U.S. SENATE. Committee on Foreign Relations, "Convention on the Protection of Children 
and Co-Operation in Respect of Intercountry Adoption,” Report, April 27, 2000. Washington, DC, Government Printing Office (Senate Exec. Rept. 106-14, 106th Congress, 1st Session), 2000.

U.S. SENATE. Committee on Foreign Relations, "The Optional Protocol to the Convention on the Rights of the Child on the Sale of Children, Child Prostitution and Child Pornography and The Optional Protocol to the Convention on the Rights of the Child on the Involvement of Children in Armed Conflict," Report, June 12, 2002. Washington, DC, Government Printing Office (Senate Exec. Rept. 107-4, 107th Congress, 2d Session), 2002a.

U.S. SENATE. Committee on Foreign Relations, "Convention on the Elimination of All Forms of Discrimination Against Women,” Report, September 6, 2002. Washington, DC, Government Printing Office (Senate Exec. Rept. 107-9, 107th Congress, 2d Session), 2002b

U.S. SENATE. Committee on Foreign Relations, "Convention on the Rights of Persons with Disabilities,” Report, July 31, 2012. Washington, DC, Government Printing Office (Senate Exec. Rept. 112-6, 112th Congress, 2d Session), 2012.

U.S. SENATE. Committee on Foreign Relations, "Convention on the Rights of Persons with Disabilities,” Report, July 28, 2014. Washington, DC, Government Printing Office (Senate Exec. Rept. 113-12, 113th Congress, 2d Session), 2014. 